\title{
Properties of cemented backfill prepared on the basis of selected Coal Combustion Products (CCPs)
}

\author{
Piotr Pierzyna \\ Silesian University of Technology, Gliwice, Poland
}

\begin{abstract}
SUMMARY: The article presents the results of research on the physico-mechanical properties of Cemented Paste Backfill mixtures (CPB) produced from low-calcium fly ash from a conventional boiler and from slag taken from a fluidized bed boiler with the addition of metallurgical cement in the amount of $5-15 \mathrm{wt} \%$. Fly ash and slag were mixed in big quantities in various proportions. The tested mixtures with a constant concentration of solids to water of $62 \mathrm{wt} \%$ were characterized by a wide range of consistency: from paste to very liquid. The conducted research demonstrates that the best results were obtained for the mixtures with ash to slag ratio of $75: 25 \mathrm{wt} \%$.
\end{abstract}

Keywords: Cemented paste backfill, Coal Combustion Products, Mechanical property

\section{INTRODUCTION}

Wastes generated by power industry or mining industry have been widely used in civil engineering for many years, i.e. in road engineering, construction, land reclamation, as well as in mining. Wastes from the energy sector are of particular technological importance for Polish hard coal mining industry. They are most often used in the backfilling technology of goafs and to eliminate inactive workings, usually dog headings. And postmining waste in the form of crushed gangue is used by Polish hard coal mines only in traditional hydraulic backfill, which is applied infrequently. In contrast, in ore mining industry they use both typical hydraulic backfill (for example KGHM Polska Miedź) and solidified backfill (for example ZG "Trzebionka"). In room-and-pillar systems used by ore mining industry, massive pillars, which were left behind to ensure stability, limit mining operations. The use of solidified backfill allows for safe extraction of ore remaining in the pillars and ensures long-term stability of the mined-out areas (Jung \& Biswas, 2002). A typical hydraulic backfilling is made of sand. And the solidified backfill is usually made of dehydrated post-flotation waste and cement, forming the so-called cemented paste backfill (CPB). Other additives that are used in that type of backfilling are: lime, fly ash and metallurgical slag (Belem \& Benzaazoua, 2004). The paste-type solidified backfills are usually pumped over large horizontal distances $(1 \mathrm{~km})$ using concrete pumps. However, more frequently the feeding of the mixtures to the void to be filled up is done by gravity, using mixtures of liquid consistency (Brackebusch, 1995). 


\section{MATERIAL AND METHODS}

The following wastes from power-generation plants were used to produce CPB mixtures:

- fly ash from conventional boilers (code 100102 ),

- slag from fluidized bed boilers (code 100124 ).

The used wastes were from selected power plants located in southern Poland where hard coal is burned.

The metallurgical cement CEM III/A $42.5 \mathrm{~N}$ - LH/HSR/NA was used as the binder. It is characterized by low content of alkali (NA) and high resistance to corrosive agents (HSR) (Shi, 2003). Its application states to reason due to the use of slag from fluidized bed boilers, which is generally characterized by a high content of sulfates (Qian et al., 2008), (Z. Zhang et al., 2012). Another aspect of using this type of cement involves the presence of acid and saline waters in the mines (PluTa, 2006), (Singh, 1988)(Skoczyńska-Gajda \& Labus, 2012), which is a highly corrosive environment.

Fly ash and slag were mixed in large volume in various proportions, replacing one component with another with a step of $25 \mathrm{wt} \%$. To the wastes and mixtures thereof, cement was added in the amount of 5, 10 and $15 \mathrm{wt} \%$. In this way, ash-cement, ash-slag-cement and slagcement mixtures were produced. In total, 15 CPB mixtures were investigated. Table 1 presents the proportioning of the mix for all CPB samples.

Dry components (fly ash, slag, cement) were homogenized in a mixer for $3 \mathrm{~min}$ before being combined with water. Then water was added and the whole was further stirred for $2 \mathrm{~min}$. The prepared mixtures had a constant solids/water concentration of $62 \%$. The proportions of water and solids $(\mathrm{W} / \mathrm{S}$ ratio $=0.38)$ were selected so that the resulting mixtures had mainly a liquid consistency, as well as that of pastes. Liquid consistency results from the fact that the transport of mixtures from the surface to an underground working, in line with the conditions of Polish mining, takes place in a gravitational way (Palarski et al., 2014). The fluidity of the mixture determines, among others, their transport and penetration capabilities (Piotrowski \& Mazurkiewicz, 2006) (Palarski et al., 2005).

The tests on the chemical composition in oxide form of ash and slag were carried out using the X-ray fluorescence (XRF) method, with the application of the spectrometer Epsilon 1 by PANalytical.

The tests of CPB mixtures were carried out in line with the backfill Standard PNG-11011:1998 in force in Poland "Materials for solidified backfill and caulking of goafs.

Table 1. Cemented paste backfill (CPB) mixture formulations.

\begin{tabular}{llll}
\hline Proporcja Fly ash/Slag & Fly ash [wt $\%]$ & Slag $[\mathrm{wt} \%]$ & CEM III $[\mathrm{wt} \%]$ \\
\hline- & 0 & 95 & 5 \\
$1: 3$ & 23,75 & 71,25 & 5 \\
$2: 2$ & 47,5 & 47,5 & 5 \\
$3: 1$ & 71,25 & 23,75 & 5 \\
- & 95 & 0 & 5 \\
- & 0 & 90 & 10 \\
$1: 3$ & 22,5 & 67,5 & 10 \\
$2: 2$ & 45 & 45 & 10 \\
$3: 1$ & 67,5 & 22,5 & 10 \\
- & 90 & 0 & 10 \\
- & 0 & 85 & 15 \\
$1: 3$ & 21,25 & 63,75 & 15 \\
$2: 2$ & 42,5 & 42,5 & 15 \\
$3: 1$ & 63,75 & 21,25 & 15 \\
- & 85 & 0 & 15 \\
\hline
\end{tabular}

Source: own study. 
Requirements and tests" (Norma PN-G-11011:1998). The above Standard should meet the following requirements:

1. flowability test - minimum $90 \mathrm{~mm}$,

2. density - minimum $1.2 \mathrm{Mg} / \mathrm{m}^{3}$,

3. volume of supernatant water - maximum $7 \%$,

4. setting time - individually determined for local conditions of using solidified backfill,

5. compressive strength - minimum 0.5 $\mathrm{MPa}$,

6. slaking - maximum $20 \%$.

The paper presents the basic parameters such as melt flowability and compressive strength. In order to map typical climatic conditions occurring in underground mine workings, the prepared samples of mixtures were seasoned in the LTB $650 \mathrm{RV}$ climate chamber by Elbanton, the Netherlands. The seasoning conditions in the chamber were as follows: temperature $25^{\circ} \mathrm{C} \pm 1{ }^{\circ} \mathrm{C}$, humidity $90 \% \pm 2 \%$.

The consistency of tested mixtures was determined by flowability tests. To measure the consistency of paste-type backfill mixtures, the cone slump test method is often used, which consists in measuring the decrease in the height of the mixture accumulated in the measuring cylinder (cone) (Clayton et al., 2003). This test is of no use for mixtures with liquid consistency. In such a case, all the mixture accumulated in the measuring cylinder flows out of it and does not create the typical slump cone, but it creates a flow cake. The diameter of the resulting flow cake is a measure of flowability test, as illustrated in Figure 1. Thus, the measurement of consistency using the cone slump method after obtaining the maximum (limit) slump height corresponding to the height of the used measuring cylinder can be carried out just by measuring the flowability. The flowability tests were carried out using a cone of the dimensions: top $\mathrm{D}=35 \mathrm{~mm}$, base $\mathrm{D}=63 \mathrm{~mm}$, height $\mathrm{H}=60 \mathrm{~mm}$, which is in line with the Polish backfill Standard PN-G-11011:1998.

A peculiar (atypical) parameter for the Polish mining area is setting time. For this reason, it requires a broader presentation. According to the Polish standard PN-G 11011:1998 (Norma PN-G-11011:1998, n.d.) setting time is the time required to obtain a load capacity of 0.51 $\mathrm{MPa}$. The measurement is made with a modified Vicat apparatus. It consists in measuring the

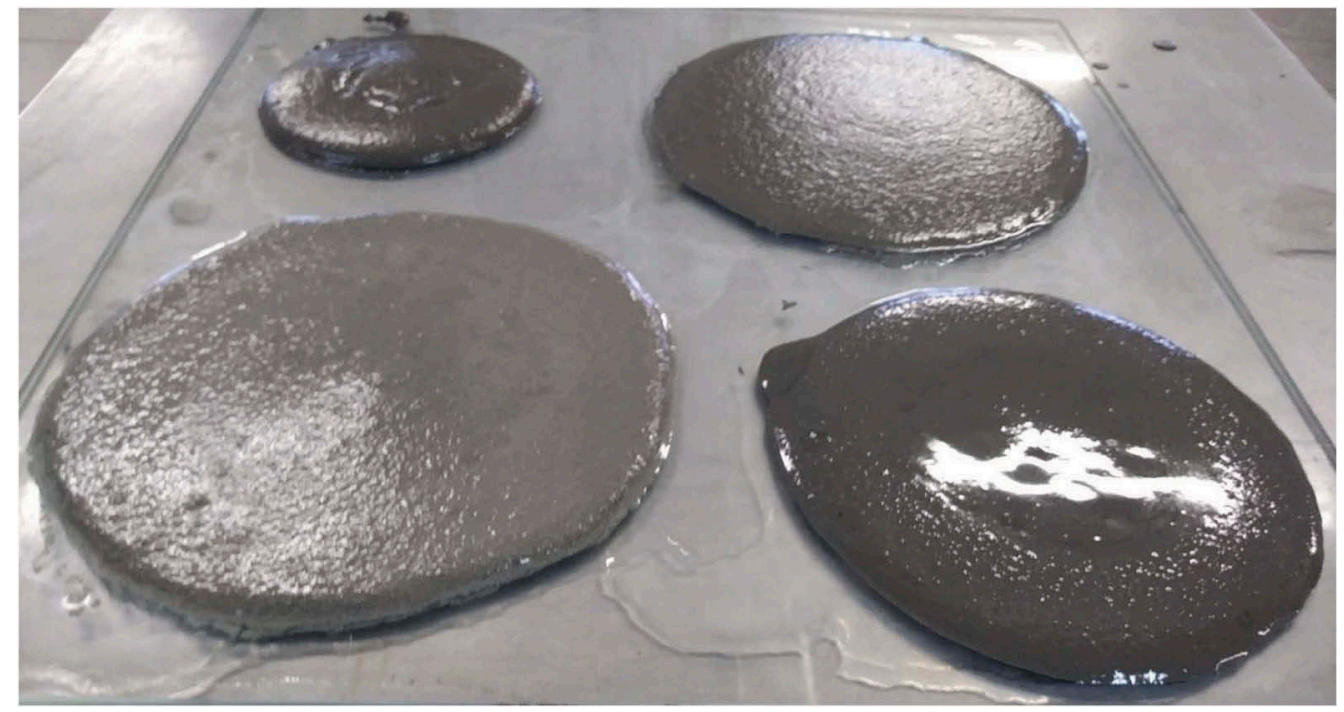

Figure 1. Exemplary flow cakes being a measure of flowability.

Source: own study. 
immersion depth of a $1 \mathrm{~cm}^{2}$ penetrator into the sample under the specified weight exerted by the moving part of the apparatus. The sample of the tested material is placed in an identical ring which is used in the traditional cement setting time test. The setting time is assumed to be the time after which the penetrator has immersed in the sample to a depth not lower than $3 \mathrm{~mm}$ with a moving part weight of $5.0 \mathrm{~kg}$, which corresponds to the load capacity of $0.51 \mathrm{MPa}$.

And slaking is the percentage change in compressive strength caused by the impact of water. Usually, it refers to its loss. For this purpose, the samples of the tested CPB mixtures, after 28 days of seasoning in a humid air environment (climatic chamber) are subjected to water impact by immersing them for 24 hours. After that, the hydrated samples are subjected to a compressive strength test which is referenced to the strength obtained after 28 days of seasoning in the humid air environment. The compressive strength tests and slaking tests were tested on cylindrical samples of the height and diameter of $100 \mathrm{~mm}$.

\section{RESULTS AND DISCUSSION}

\subsection{Chemical composition}

The chemical composition in oxide form applied in the tests of ash from a conventional boiler and slag from a fluidized bed boiler is presented in Table 2.

The ash and slag used for the tests differ primarily in the content of $\mathrm{CaO}$ and $\mathrm{SO}_{3}$, and to a lesser extent in the content of $\mathrm{Al}_{2} \mathrm{O}_{3}$. Ash contains more aluminum. In contrast, slag contains much more lime, in particular its free form, as well as more sulfates. This is due to the fact that the slag comes from a fluidized bed boiler, where the dry flue gas desulphurization method is used. LOI is also very diverse. The content of free lime, sulfur or LOI in the ashes increases their demand for water, i.e. their water demand increases (Tsimas \& MoutsatsouTsima, 2005). Bearing in mind the guidelines of the American ASTM C618 standard in terms of the content of silicon, aluminum and iron, fly ash can be classified into class F (LCFA) (ASTM, 2012). Taking into account the content of lime, including its free form in relation to the combined content of silicon, aluminum and iron, i.e. the hydraulic module $\left(\mathrm{M}_{\mathrm{h}}\right)($ Sitko, 2016) (Wirska-Parachoniak, 1968) amounting to 0.23 , we can state that this slag has low binding properties (Pierzyna, 2017). For example, for Portland cement, the hydraulic module is in the range 1.7-2.4 (Nakano et al., 2007)

Table 2. Chemical composition of ash from a conventional boiler and slag from a fluidized bed boiler.

\begin{tabular}{lll}
\hline Chemical ingredient & Fly ash & Slag \\
\hline & {$[\%$ by mass] } & {$[\%$ by mass] } \\
\hline $\mathrm{SiO}_{2}$ & 50,61 & 43,83 \\
$\mathrm{Al}_{2} \mathrm{O}_{3}$ & 26,03 & 19,85 \\
$\mathrm{Fe}_{2} \mathrm{O}_{3}$ & 6,30 & 4,79 \\
$\mathrm{CaO}$ & 3,20 & 15,68 \\
$\mathrm{MgO}$ & 1,77 & 1,74 \\
$\mathrm{Na} 2$ & 0,93 & 1,09 \\
$\mathrm{~K}_{2} \mathrm{O}$ & 2,89 & 2,03 \\
$\mathrm{SO}_{3}$ & 0,70 & 9,08 \\
$\mathrm{TiO}_{2}$ & 1,09 & 0,68 \\
$\mathrm{P}_{2} \mathrm{O}_{5}$ & 0,47 & 0,09 \\
$\mathrm{CaO}$ free & 0,21 & 3,21 \\
$\mathrm{LOI}$ & 5,17 & 0,77 \\
$\mathrm{Total}$ & 99,16 & 99,63 \\
\hline
\end{tabular}

Source: own study. 


\subsection{Grain size}

The grain size of ash and slag applied in the study was determined using the traditional sieve analysis as presented in Figure 2.

The grain size of fly ash is below $1 \mathrm{~mm}$, with approximately $80 \%$ of the fraction being below $0.063 \mathrm{~mm}$. For example, ash with similar grain size was used in the studies presented in (X. Zhang et al., 2017). And the slag used in the studies had the grain size lower than $4 \mathrm{~mm}$. However, the share of fraction below $0.063 \mathrm{~mm}$ in the slag is small compared to ash, being below $2 \%$. Taking into account the fraction below $1 \mathrm{~mm}$, which is the total grain size of ash, we can observe that in the slag it is around $83 \%$. Yet, the content of grains below $0.125 \mathrm{~mm}$ in the ash is at the level of $90 \%$, while in the slag it is about $10 \%$. According to the granulometric classification recommended by the USDA (United States Department of Agriculture) (NRCS, 1993) or WRB (World Reference Base for Soil Resources) (WRB, 2015), the slag presented in its entirety can be classified as sand fraction. The said waste in the Polish nomenclature relating to the Waste Catalog is referred to as bottom sand (code 100124$)$. And the fly ash according to the above classifications can be classified to a significant extent as dusty fraction (about $75-80 \%)$, and the rest as sandy fraction.

\subsection{Flowability of mixtures}

For gravity transport, a sufficiently fluid consistency is required, which can be characterized by the flowability test of the mixture. In the conditions of Polish mines, and in terms of installations and pipelines applied in them, the gravitationally transportable mixtures are the ones that reach the flowability higher than about $140 \mathrm{~mm}$ (Jendrus et al., 2008). It is often $300 \mathrm{~mm}$ or higher. The fluidity of the mixture, and thus its flowability, is related to the transport distance as well as the range of its spread in the excavation and the penetration capacity into the

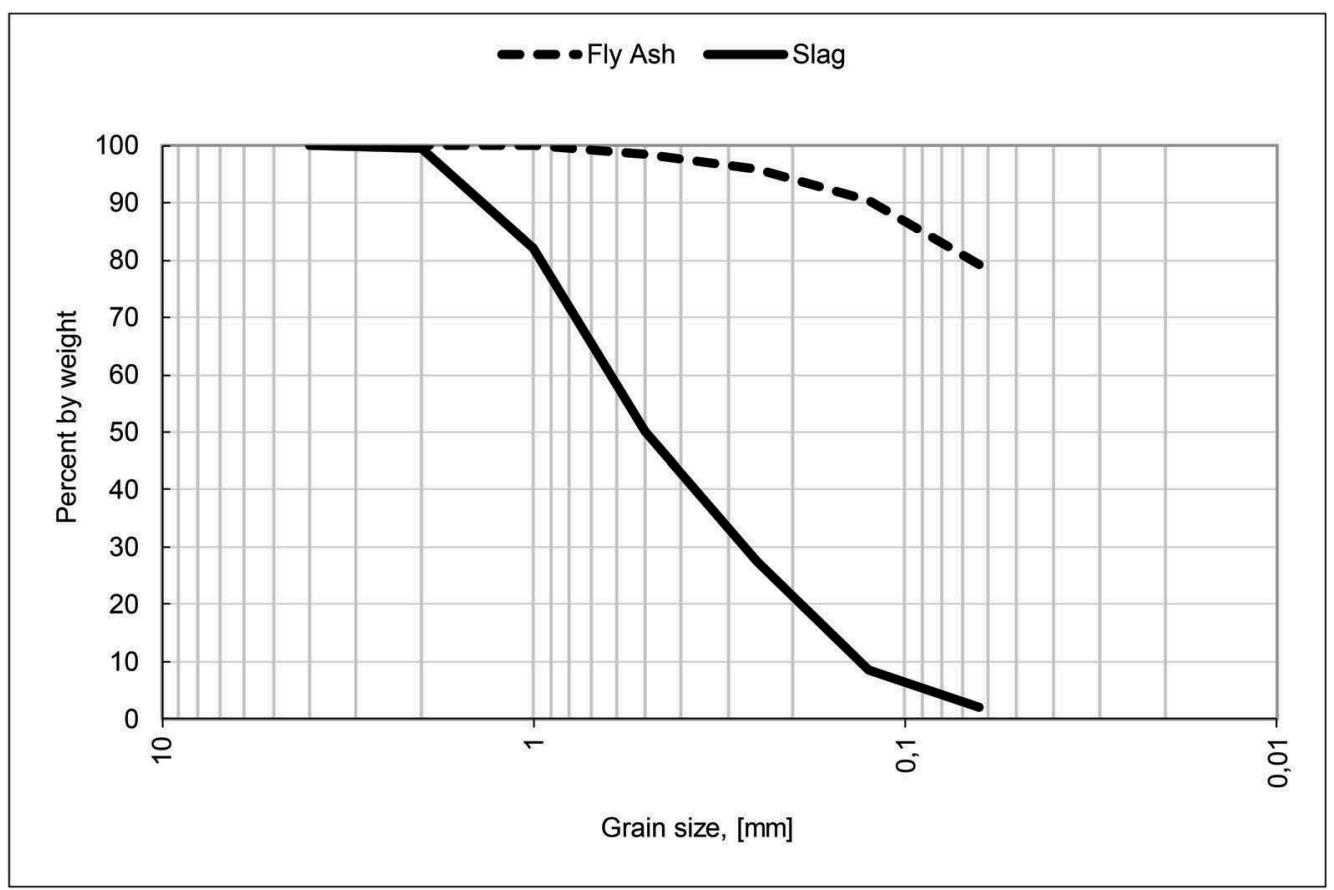

Figure 2. Grain composition curves of the ash and slag used in the study.

Source: own study. 
goaf debris (Palarski et al., 2005; Piotrowki \& Mazurkiewicz, 2006; Yin et al., 2012). Along with the change in the flowability of the mixtures, their rheological properties change: first of all the yield strength and density (Plewa et al., 2006; Strozik, 2010, 2018). These parameters, in turn, depend on the chemical composition, specific gravity of the particles and their size, i.e. grain size of individual components, and ultimately that of the CPB mixture (Clayton et al., 2003). The flowability of the tested CPB mixtures having the constant index $\mathrm{w} / \mathrm{s}=0.38$ is presented in Table 3.

The flowability was determined for all mixtures except for two slag-cement mixtures with the addition of 5 and $10 \mathrm{wt} \%$ cement. In that case, no regular shape of spread cake was obtained, in contrast to the slag-cement mixture with the share of $15 \mathrm{wt} \%$ cement, as illustrated in Figure 3. The slag used in the test is characterized by grain size typical for the sandy fraction. Thus, its sedimentation is immediate, which is obvious. The share of cement in the amount of 5 and $10 \mathrm{wt} \%$ was insufficient to form a suspension which would not undergo sedimentation in the short time of flowability testing. The suitable suspension which could be subjected to flowability testing was ensured by the share of $15 \mathrm{wt} \%$ cement, with $85 \mathrm{wt} \%$ slag.

The conducted studies demonstrate that the flowability of the tested mixtures depends primarily on the proportion of slag and ash, and to a lower extent on the share of cement. Depending on the proportion of slag and ash, the rise of the share of cement from $5 \mathrm{wt} \%$ to $15 \mathrm{wt} \%$ brings about a slight decrease or increase in flowability, by a maximum of $15 \mathrm{~mm}$. However, taking into account the impact of the slag and ash ratio, we can state that the rise of ash share brings about a very significant decrease of flowability from about $215 \mathrm{~mm}$ to about $140 \mathrm{~mm}$. In the case of ash-cement mixtures, it may be too exaggerated to state that they have liquid consistency, which is measured by flowability. The obtained spread cakes have regular shapes (Figure 4). Yet, referring to their dimensions: diameter about $100 \mathrm{~mm}$ and height about $20 \mathrm{~mm}$, it would be more appropriate to state that these mixtures have paste-

Table 3. Flowability of the tested CPB mixtures.

\begin{tabular}{lllll}
\hline Fly ash [wt $\%]$ & Slag [wt $\%]$ & \multicolumn{3}{c}{ Flowability [mm] } \\
\hline \multirow{3}{*}{0} & $5 \%$ CEM & $10 \%$ CEM & $15 \%$ CEM \\
25 & 100 & not determined & not determined & 217 \\
50 & 75 & 217 & 213 & 215 \\
75 & 50 & 195 & 190 & 185 \\
& 25 & 141 & 145 & 153 \\
100 & & lack of flowability & lack of flowability & lack of flowability \\
& \multirow{2}{*}{0} & $(94 \mathrm{~mm})$ & $(100 \mathrm{~mm})$ & $(102 \mathrm{~mm})$ \\
& & slump height $=36 \mathrm{~mm}$ & slump height $=39 \mathrm{~mm}$ & slump height $=40 \mathrm{~mm}$ \\
& & pasta & pasta & pasta \\
\hline
\end{tabular}

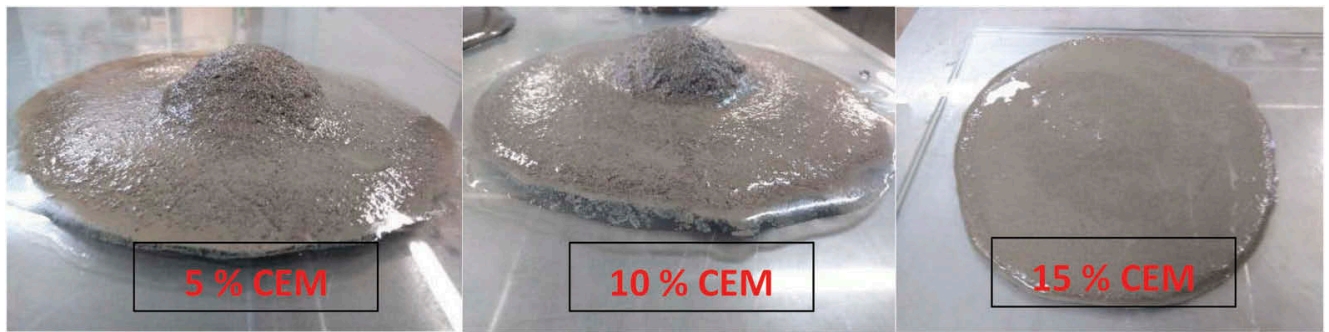

Figure 3. Obtained shapes of spread cakes of the ash-cement mixtures.

Source: own study. 


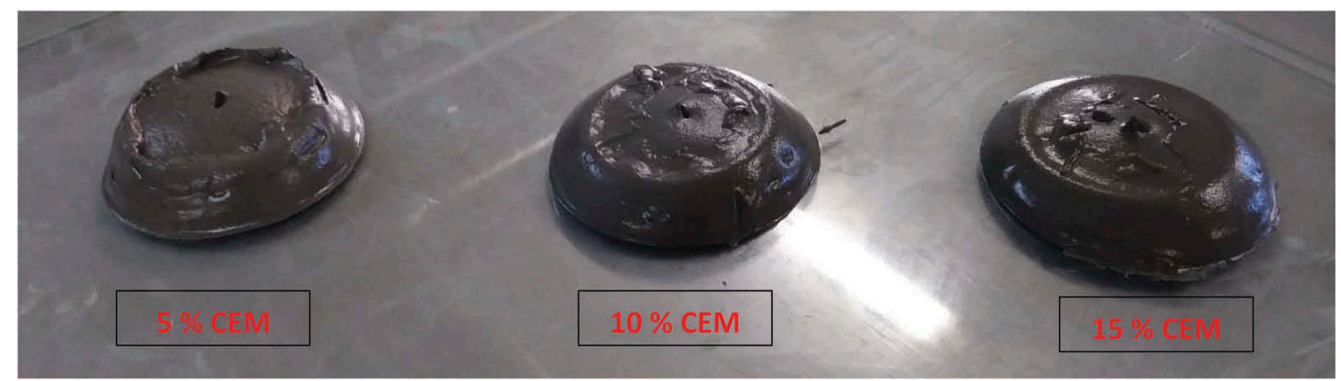

Figure 4. Uzyskane kształty placków rozpływowych mieszanin popiołowo-cementowych.

Source: own study.

like consistency. In that case it would be appropriate to use the slump cone test as a measure of consistency. The cone slump height of ash-cement mixtures, depending on the cement, was changing a little only, in the range from $94 \mathrm{~mm}$ to $102 \mathrm{~mm}$.

\subsection{Compressive strength}

The compressive strength test was carried out after 7, 14, 28 and 90 days of seasoning of the samples in the climactic chamber. The compressive strength of CPB mixtures depending on the proportions of ash and slag and the proportion of cement are presented in Figure 5.

The presented research results demonstrate that regardless of the curing time, slag-cement mixtures (without ash) are always characterized by the lowest strength, while the highest strength have the mixtures with the ash to slag ratio of 75:25 wt \%. And the ash-cement mixtures (without the share of slag) have similar strengths to the slag-cement mixtures. Figure 6

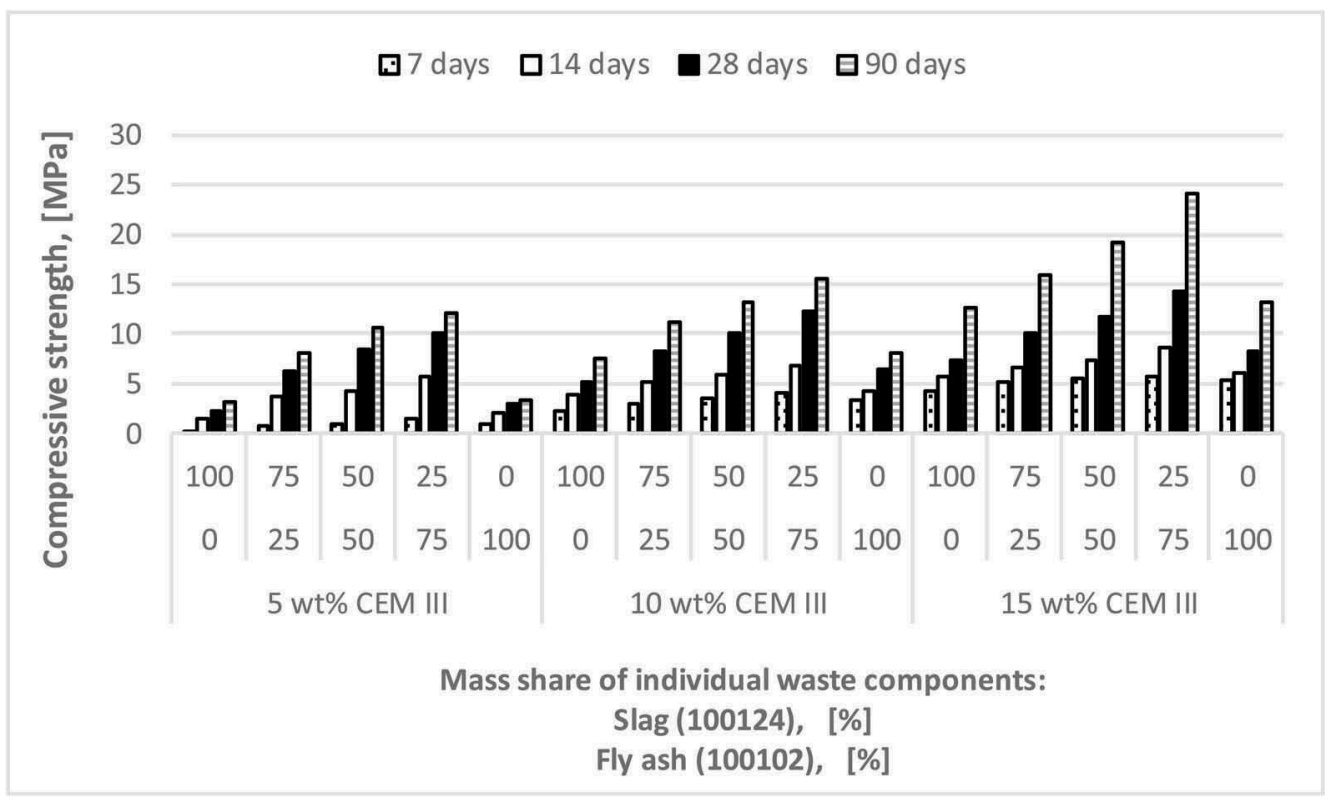

Figure 5. Compressive strength of CPB mixtures depending on the proportions of ash and slag and cement share.

Source: own study. 


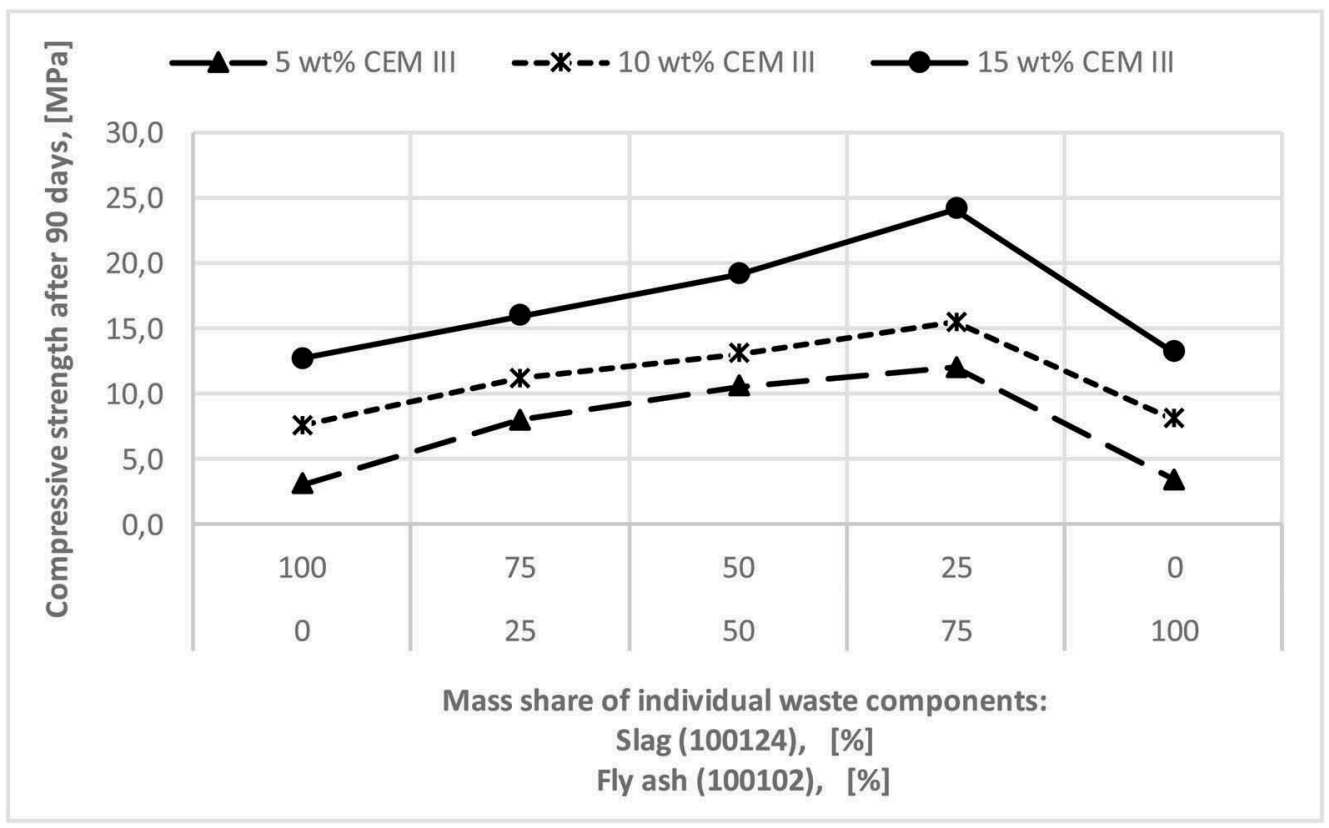

Figure 6. Compressive strength of CPB mixtures after 90 days, depending on proportion of ash to slag and the share of cement.

Source: own study.

presents the compressive strength of the investigated CPB mixtures after 90 days of curing, depending on the ash to slag ratio and the share of cement.

Having analyzed the obtained results of strength tests, depending on the proportions of ash and slag, we must say that the rise of the share of ash within the range of $0-75 \mathrm{wt} \%$ results in a systematic increase in strength. The rise of ash content to $100 \mathrm{wt} \%$ (exclusion of slag) results in a drastic decrease of strength to the level achieved by the slag-cement mixtures.

Such a behavior is characteristic for all cement shares, and it occurs in all research time periods (Figure 5). The mixtures of the ash to slag ratio of 75:25 $\mathrm{wt} \%$ with respect to twocomponent mixtures (slag-cement and ash-cement) reached after 90 days about 4 times (for 5 $\mathrm{wt} \%$ cement) and about 2 times (for 10 and $15 \mathrm{wt} \%$ cement) higher compressive strength.

\section{CONCLUSIONS}

The carried out studies demonstrate the impact of ash and slag proportions and the share of cement in the range of $5-15 \mathrm{wt} \%$ on the mechanical parameters of the developed CPB mixtures of the mass share of water to solids being W/S $=0.38$.

As to compressive strength, the rise of the share of fly ash at the expense of slag in the range up to $75 \mathrm{wt} \%$ results in its significant increase. But further rise of the share of ash content to $100 \mathrm{wt} \%$ (exclusion of slag) results in a drastic decrease in strength to the level achieved by the slag-cement mixtures (without the share of ash).

Two-component mixtures achieve similar compressive strengths, but the slag-cement ones are characterized by almost two times higher flowability than ash-cement mixtures.

The conducted studies show that the best results were obtained for the mixtures with the ash to slag ratio of 75:25 wt \%, which is consistent with the results of the work (Z. Zhang et al., 2012). They are characterized by the highest compressive strength after 90 days, reaching $24 \mathrm{MPa}$. 
The requirements set by the Polish standard PN-G 11011: 1998 for the materials regarded as solidified backfill (CPB) within the scope of the described physical parameters are met by all the tested mixtures.

\section{BIBLIOGRAPHY}

ASTM, C. (2012). Standard specification for coal fy ash and raw or calcined natural pozzolan for use in concrete.

Belem, T., \& Benzaazoua, M. (2004). An overview on the use of paste backfill technology as a ground support method in cut-and-fill mines. Proceedings of the 5th Int. Symp. on Ground Support in Mining and Underground Construction. Villaescusa \& Potvin (Eds. ), 28-30.

Brackebusch, F. W. (1995). Basics of paste backfill systems. International Journal of Rock Mechanics and Mining Sciences and Geomechanics Abstracts, 3(32), 122A.

Clayton, S., Grice, T. G., \& Boger, D. V. (2003). Analysis of the slump test for on-site yield stress measurement of mineral suspensions. International Journal of Mineral Processing, 70(1), 3-21. https://doi. org/10.1016/S0301-7516(02)00148-5

Jendruś, R., Lutyński, M., Pierzyna, S., \& Strozik, G. (2008). Flow and fill properties of fly ash-water slurries for grouting of cavings in underground longwall mining. Th International on TransportSedimentation of Solid Particle, 232-240.

Jung, S. J., \& Biswas, K. (2002). Review of Current High Density Paste Fill and its Technology. Mineral Resources Engineering, 11(2), 165. https://doi.org/10.1142/S0950609802000926

Nakano, T., Yokoyama, S., Uchida, S., \& Maki, I. (2007). Badania podstawowe związane z produkcją cementu z popiołu ze spalania miejskich odpadów stałych. Cz.1: Charakterystyka popiołów i cementów specjalnych. Cement Wapno Beton, $R$. 12/74, $n r$ 4, 187-192.

Norma PN-G-11011:1998. Materiaty do podsadzki zestalanej $i$ doszczelniania zrobów. Wymagania i badania.

NRCS, U. (1993). Soil survey division staff (1993) soil survey manual. Soil conservation service. US Department of Agriculture Handbook, 18, 315.

Palarski, J., Plewa, F., Pierzyna, P., \& Zając, A. (2005). Właściwości zawiesin z materiałów odpadowych $\mathrm{z}$ dodatkiem środka wiążącego $\mathrm{w}$ aspekcie możliwości ich wykorzystania do likwidacji zawodnionych szybów. Górnictwo i Geoinżynieria, R. 29, z. 4, 139-144.

Palarski, J., Plewa, F., \& Strozik, G. (2014). Filling of voids in coal longwall mining with caving-technical, environmental and safety aspects. Proceedings of the Eleventh International Symposium on Mining with Backfill, 483-491.

Pierzyna, P. (2017). Disposal of coal combustion wastes in the hydraulic backfill process. IOP Conference Series: Materials Science and Engineering, 268, 012011. https://doi.org/10.1088/1757-899X/268/1/ 012011

Piotrowski, Z., \& Mazurkiewicz, M. (2006). Chłonność doszczelnianych zrobów zawałowych. Górnictwo $i$ Geoinżynieria, R. 30, z. 3, 37-46.

Plewa, F., Strozik, G., \& Jendruś, R. (2006). Wpływ własności reologicznych mieszanin wybranych odpadów drobnofrakcyjnych na parametry ich przepływu przez gruzowisko zawałowe w świetle wyników badań laboratoryjnych. Zeszyty Naukowe. Górnictwo/Politechnika Ślaska, z. 274, 123-136.

PluTa, I. (2006). Wykorzystanie metod i technologii górniczych do oczyszczania wód kopalnianych. Wiadomości Górnicze, 57(10), 529-537.

Qian, J., Zheng, H., Song, Y., Wang, Z., \& Ji, X. (2008). Special Properties of Fly Ash and Slag of Fluidized Bed Coal Combustion. Journal of the Chinese Ceramic Society, 10.

Shi, C. (2003). Corrosion resistance of alkali-activated slag cement. Advances in Cement Research, 15(2), 77-81. https://doi.org/10.1680/adcr.2003.15.2.77

Singh, G. (1988). Impact of coal mining on mine water quality. International Journal of Mine Water, 7(3), 49-59.

Sitko, J. (2016). Modernizacja technologii zagospodarowania odpadów hutniczych. Systemy Wspomagania w Inżynierii Produkcji. http://yadda.icm.edu.pl/baztech/element/bwmetal.element.baztechcd63ed9c-7d6c-481c-b020-087f3b4123d7/c/sitko_swzp_2016_2.pdf

Skoczyńska-Gajda, S., \& Labus, K. (2012). Przegląd biernych metod oczyszczania kwaśnych wód kopalnianych. Przegląd Górniczy, 68.

Strozik, G. (2010). Ocena własności transportowych i migracyjnych mieszanin drobnofrakcyjnych do doszczelniania zrobów zawałowych w aspekcie ich własności reologicznych. Cuprum : czasopismo naukowo-techniczne górnictwa rud, $\mathrm{nr}$ 2, 95-109. 
Strozik, Grzegorz. (2018). Influence of pipe roughness and coating built-up on pipe walls on the flow of solidifying Non-newtonian fly ash-water mixtures in hydraulic transport systems in coal mines. IOP Conference Series: Earth and Environmental Science, 174, 012015. https://doi.org/10.1088/1755-1315/ $174 / 1 / 012015$

Tsimas, S., \& Moutsatsou-Tsima, A. (2005). High-calcium fly ash as the fourth constituent in concrete: Problems, solutions and perspectives. Cement and Concrete Composites, 27(2), 231-237. https://doi. org/10.1016/j.cemconcomp.2004.02.012

Wirska-Parachoniak, M. (1968). Z historii wiążących materiałów budowlanych. Ochrona Zabytków, $4,17-23$.

WRB, I. U. of S. S. W. G. (2015). World reference base for soil resources 2014 (update 2015), international soil classification system for naming soils and creating legends for soil maps. World Soil Resources Reports , FAO, Rome.

Yin, S., Wu, A., Hu, K., Wang, Y., \& Zhang, Y. (2012). The effect of solid components on the rheological and mechanical properties of cemented paste backfill. Minerals Engineering, 35, 61-66. https:// doi.org/10.1016/j.mineng.2012.04.008

Zhang, X., Lin, J., Liu, J., Li, F., \& Pang, Z. (2017). Investigation of Hydraulic-Mechanical Properties of Paste Backfill Containing Coal Gangue-Fly Ash and Its Application in an Underground Coal Mine. Energies, 10(9), 1309. https://doi.org/10.3390/en10091309

Zhang, Z., Qian, J., You, C., \& Hu, C. (2012). Use of circulating fluidized bed combustion fly ash and slag in autoclaved brick. Construction and Building Materials, 35, 109-116. 